\title{
Research of Serum Homocysteine Levels in Healthy Cows
}

\author{
Kiliçkap A and Kozat $S^{*}$
}

Department of Internal Medicine, Faculty of Veterinary Medicine, Yuzuncu Yil University, Van, Turkey

${ }^{*}$ Corresponding author: Kozat S, Department of Internal Medicine, Faculty of Veterinary Medicine, Yuzuncu Yil University, Zeve Campus, Tuşba-Van, Turkey, E-mail: skozat@hotmail.com

Citation: Kiliçkap A, Kozat S (2017) Research of Serum Homocysteine Levels in Healthy Cows. J Vet Sci Anim Husb 5(1): 103. doi: 10.15744/2348-9790.5.103

Received Date: October 24, 2016 Accepted Date: February 24, 2017 Published Date: February 27, 2017

\begin{abstract}
In this study, serum homocysteine levels aimed to determine in healthy cows (Simmental, Holstein, and Montafon). 60 culture cows (20 Simmental cows, 20 Holstein cows, and 20 montafon cows) constitute this study's materials. According to the systemic examinations, the animals used in this study were determined to be healthy. Blood samples were taken from animals according to the jugular vein technique. Homocysteine levels obtained from serum samples were measured by using the commercial test kit in accordance with the procedure of the kit. The value of serum homocysteine levels in three breeds were found close to each other. Serum homocysteine levels were determined and they are $17.44 \pm 1.22 \mu \mathrm{mol} / \mathrm{L}$ in Simmental breed, $17.04 \pm 1.13 \mu \mathrm{mol} / \mathrm{L}$ in Holstein breed, and 16.35 $\pm 1.24 \mu \mathrm{mol} / \mathrm{L}$ in Montafon breed. The CK, CK-MB, AST and LDH values of all three breeds were determined within the normal physiological limits.

As a result, the serum homocysteine values for healthy breeds of cows which can constitute a reference value were concluded in this study.
\end{abstract}

Keywords: Cow; Homocysteine; Reference Value

\section{Introduction}

Homocysteine $(\mathrm{Hc})$, formed as a result of methionine metabolism (demethylation of methionine), is an amino acid containing sulfhydryl which isn't found in the proteins [1-5]. Methionine is an essential amino acid which is produced from dietary proteins [2]. Homocysteine in the plasma has four forms: $1-2 \%$ is free, $70-80 \%$ bound to plasma proteins via disulfide link (especially albumin-bound), $20-30 \%$ depends on itself to form dimers, and the rest is found either as homocysteine dimer or a cysteinehomocysteine-cysteine mixed disulfide $[2,6]$.

Increases of the homocysteine level show less intake of foods containing vitamin $B_{12}[7,8]$, impairment of renal function $[2,8]$ or it shows that it may be due to a low level of enzyme activity in the metabolism of homocysteine [2,9] . In recent years, according to the data about hyperhomocystein, it is emphasized that the risk of atherosclerosis may decrease just by taking a simple vitamin $[5,8]$. Deficiency of folic acid, vitamin $B_{12}$ or vitamin $B_{6}$ is associated with high level of Hc. It is reported that these vitamins are necessary for the metabolism of $\mathrm{Hc}$ [7]. It is metabolized through the pathways of remethylation in which vitamin $\mathrm{B}_{12}$ becomes cofactor in the body and through the pathways of transsulfuration in which vitamin $\mathrm{B}_{6}$ becomes cofactor [10]. In human medicine it is reported that the levels of high homocysteine and low concentrations of B vitamins in the plasma are the risk factors for coronary, cerebral atherosclerosis and peripheral vascular diseases [11].

Cobalt is required for rumen microorganisms to synthesis vitamin $\mathrm{B}_{12}$. In addition, it is reported that as a result of the insufficient function of methionine synthesis due to Vitamin $B_{12}$, homocysteine level was increased [12,13]. A high level of homocysteine in the body causes proliferation of the vascular endothelium, platelets, and collagen and decreases the vitality of the nitric oxide [14].

In this study, homocysteine levels of healthy culture breed cows were determined according to their age and sex groups. It is aimed to use these obtained normal values of homocysteine as an additional parameter to the parameters currently used for diagnosis, prognosis, and treatment of the cardiovascular diseases of the cows.

\section{Materials and Methods}

The material in this study consisted of 60 healthy culture breed cows which obtained from Van and its vicinity. All animals were found healthy on clinical examination by checking body temperature, respiratory and heart beat frequency and general clinical appearance. All animals were divided into three groups based on their breeds (Simmental, Holstein, and Montafon) 
and each group included 20 cows. Cows were not applied any antibiotic Blood samples were taken from all cows according to jugular vein technique and they were taken into tubes with anticoagulant for the hematological parameters and sera tubes for biochemical analysis. After allowing to the tubes clotting by staying at room temperature, sera tubes were centrifuged ( $3000 \mathrm{rpm}$, 10 minutes). Obtained serum samples were kept in the serum storage tubes in the refrigerator in $-20^{\circ} \mathrm{C}$ until the analysis day. In the same day, analysis of hematological parameters was completed. Serum Hc levels were determined by ELISA using commercial kit (Homocysteine AXIS, Catalog no: 802865065) as described in the procedure. Measurement of serum vitamin $B_{12}$ was performed with autoanalyser (Elecyc 2010 Roche Hitachi-Japan) device. Measurement of serum cobalt was performed with the device ICP-M found in the Department of Scientific Practice Center in the Yuzuncu Yil University. Within the obtained serum, level of creatine kinase (CK), lactac dehydrogenase (LDH), aspartate aminotransferase (AST), alanine aminotransferase (ALT) and cardiac origin creatine kinase (CK-MB) were spectrophotometrically measured with the commercial test kit (Randox ${ }^{\circledR}$-UK) according to the specified procedures (5010 Photometer Boehringer Mannheim). On the day of the study, hematocrit value (Hct), hemoglobin concentration $(\mathrm{Hb})$, white blood cell count (WBC), platelet count (PLT) and mean corpuscular hemoglobin concentration (MCHC) values of blood samples in anticoagulant (EDTA) tubes were measured by blood counting device (QBC vetautoreader ${ }^{\circledR}$-IDEXX).

\section{Statistical Analysis}

Statistical evaluation of the obtained data was performed with one-way test using SPSS 9.0 statistical software program.

\section{Results}

\section{Clinical Findings}

It was determined that all of the culture breed cows (Simmental, Holstein, Montafon) used in this study were healthy according to the clinical examinations considering evaluation criteria of the systemic examination (body temperature, heart rate, respiratory rate, rumen motility). Classification by age and breed was given in the Table 1.

\begin{tabular}{|c|c|c|c|}
\hline Parameters & $\begin{array}{c}\text { Simmental } \\
(\mathbf{n}=\mathbf{2 0})\end{array}$ & $\begin{array}{c}\text { Holstein } \\
(\mathbf{n}=\mathbf{2 0})\end{array}$ & $\begin{array}{c}\text { Montafon } \\
(\mathbf{n}=\mathbf{2 0})\end{array}$ \\
\hline Body Temperature $\left({ }^{\circ} \mathrm{C}\right)$ & $37.67 \pm 0.14$ & $37.89 \pm 0.14$ & $37.79 \pm 0.17$ \\
\hline Heart rate (Beats/Min) & $66.95 \pm 2.06$ & $70.70 \pm 1.36$ & $68.40 \pm 1.86$ \\
\hline Respiratory rate (Breaths/Min) & $17.55 \pm 1.23$ & $19.15 \pm 1.12$ & $19.45 \pm 1.09$ \\
\hline Rumen motility (times/five Min) & $9.55 \pm 0.49$ & $10 \pm 0.45$ & $9.80 \pm 0.45$ \\
\hline Age (Month) & $50.20 \pm 4.99$ & $53.40 \pm 4.03$ & $49.50 \pm 3.02$ \\
\hline
\end{tabular}

Table 1: Clinical findings and age in the healthy culture breeds cows

According to the evaluation based on three breeds, clinical findings were found close to each other in the study (P > 0.05) and no statistical difference was detected (Table 1).

\section{Biochemical Findings}

Serum AST, ALT, CK, LDH and CK-MB of healthy culture breed cows are given in Table 2.

\begin{tabular}{|c|c|c|c|}
\hline Parameters & $\begin{array}{c}\text { Simmental } \\
(\mathbf{n}=\mathbf{2 0})\end{array}$ & $\begin{array}{c}\text { Holstein } \\
(\mathbf{n}=\mathbf{2 0})\end{array}$ & $\begin{array}{c}\text { Montafon } \\
(\mathbf{n}=\mathbf{2 0})\end{array}$ \\
\hline $\mathrm{CK}(\mathrm{IU} / \mathrm{L})$ & $243.30 \pm 17.59$ & $237.80 \pm 18.19$ & $273.25 \pm 29.02$ \\
\hline $\mathrm{CK}-\mathrm{MB}(\mathrm{IU} / \mathrm{L})$ & $287.42 \pm 27.04$ & $311.33 \pm 31.81$ & $301.10 \pm 27.00$ \\
\hline $\mathrm{AST}(\mathrm{IU} / \mathrm{L})$ & $93.40 \pm 5.11$ & $90.31 \pm 4.51$ & $92.87 \pm 4.58$ \\
\hline $\mathrm{ALT}(\mathrm{IU} / \mathrm{L})$ & $31.33 \pm 1.96$ & $32.06 \pm 2.08$ & $34.19 \pm 2.12$ \\
\hline $\mathrm{LDH}(\mathrm{IU} / \mathrm{L})$ & $1553.38 \pm 169.53$ & $1453.48 \pm 159.53$ & $1644.43 \pm 167.28$ \\
\hline
\end{tabular}

Table 2: Biochemical parameters in healthy culture breeds cows

On the assessment based on breeds, it was seen that there wasn't any differences among the three breeds in the serum levels of AST, ALT, LDH, CK and CK-MB (P > 0.05) (Table 2).

\section{Hematological Findings}

Hematocrit, hemoglobin, WBC, PLT, and MCHC parameters of culture breed cows used in the study were given in Table 3.

Hematological parameters in healthy culture breed cows were found close to each other. Hematological parameters of Holstein cows 
were numerically found slightly higher than hematologic parameters of Simmental and Montafon cows. Comparative statistical analysis performed among breeds was not significant $(\mathrm{P}>0.05)$.

\begin{tabular}{|c|c|c|c|}
\hline Parameters & $\begin{array}{c}\text { Simmental } \\
(\mathbf{n}=\mathbf{2 0})\end{array}$ & $\begin{array}{c}\text { Holstein } \\
(\mathbf{n}=\mathbf{2 0})\end{array}$ & $\begin{array}{c}\text { Montafon } \\
(\mathbf{n}=\mathbf{2 0})\end{array}$ \\
\hline $\mathrm{X} \pm S \bar{x}$ & $\bar{X} \pm S \bar{x}$ & $\bar{X} \pm \mathbf{x}$ \\
\hline Hemoglobin $(\mathrm{g} / \mathrm{dl})$ & $10.61 \pm 0.26$ & $11.33 \pm 0.34$ & $11.00 \pm 0.30$ \\
\hline Hematocrit $(\%)$ & $32.70 \pm 0.67$ & $34.56 \pm 0.72$ & $34.66 \pm 0.83$ \\
\hline PLT $\left(10^{9} / \mathrm{L}\right)$ & $673.85 \pm 43.84$ & $704.25 \pm 55.01$ & $665.10 \pm 23.82$ \\
\hline MCHC $(\mathrm{g} / \mathrm{dl})$ & $31.80 \pm 0.49$ & $32.70 \pm 0.63$ & $32.44 \pm 0.51$ \\
\hline
\end{tabular}

Table 3: Hematological parameters in healthy cows

Classification of the levels of serum homocysteine, serum vitamin $\mathrm{B}_{12}$ and serum cobalt of all of the animal breeds included in the study are showed breed by breed and also their average values are showed in Table 4.

\begin{tabular}{|c|c|c|c|}
\hline Parameters & $\begin{array}{c}\text { Simmental } \\
(\mathbf{n}=\mathbf{2 0})\end{array}$ & $\begin{array}{c}\text { Holstein } \\
(\mathbf{n = 2 0})\end{array}$ & $\begin{array}{c}\text { Montafon } \\
(\mathbf{n}=\mathbf{2 0})\end{array}$ \\
\hline Homocystein $(\mu \mathrm{mol} / \mathrm{L})$ & $17.44 \pm 1.22$ & $17.04 \pm 1.13$ & $16.35 \pm 1.24$ \\
\hline Cobalt $(\mathrm{ppb})$ & $431.35 \pm 22.65$ & $483.59 \pm 31.19$ & $458.26 \pm 43.38$ \\
\hline Vitamin $\mathrm{B}_{12}(\mathrm{pg} / \mathrm{ml})$ & $192.36 \pm 22.02$ & $253.50 \pm 26.73$ & $183.74 \pm 22.22$ \\
\hline
\end{tabular}

Table 4: Levels of serum homocysteine, cobalt and vitamin $B_{12}$ in healthy cows

\section{Discussion}

Homocysteine is assessed among the factors that plays role in cardiovascular diseases, and is reported as an important parameter in the diagnosis of them [15]. In human medicine, though many studies have been done on the effects of homocysteine about the cardiovascular system $[5,11,14]$. There have not been many research reference values for cattle on this subject in the field of veterinary medicine.

This study was carried out to obtain normal physiological values of serum homocysteine levels in the culture breed cows and to demonstrate the usage of these detected homocysteine levels in diagnosis, prognosis and treatment of cardiovascular diseases.

To determine whether three breed cows used in this study were healthy or not, as a basic principle all animals were systematically examined. In this systemic examination, the body temperature of Simmental breed were $37.67 \pm 0.14$ and Holstein breed is $37.89 \pm$ $0.14^{\circ} \mathrm{C}$ and Montafon breed was $37.79 \pm 0.17^{\circ} \mathrm{C}$. Heart rates were respectively: $66.95 \pm 2.06$ beats/min. for Simmental breed, 70.70 \pm 1.36 beats/min. for Holstein breed and $68.40 \pm 1.86$ beats/min for Montafon breed. Respiratory rates were: $17.55 \pm 1.23$ breaths/ min. for Simmental breed, $19.15 \pm 1.12$ breaths/min. for Holstein breed and $19.45 \pm 1.09$ breaths/min. for Montafon breed. Rumen motilities were: $9.55 \pm 0.49$ times $/ 5 \mathrm{~min}$. for Simmental breed, $10 \pm 0.45$ times $/ 5 \mathrm{~min}$. for Holstein breed and $9.80 \pm 0.45$ times/ five minutes for Montafon breed. Values of these clinical findings show that the reference values for healthy cattle were found to be in compliance [16,17]. Considering these findings on the basis of breed, no difference was observed in these three breeds of cows and the difference was not significant in the comparative statistical analysis of data of each of the three breeds $(\mathrm{P}>0.05)($ Table 1$)$.

In the study of human medicine, a raised level of homocysteine has been estimated to be a greater risk factor (20 - 40 - fold) than an increased level of cholesterol (1-3-fold), high blood pressure (8 - 18-fold) or cigarette smoking (3.5 - fold) [15]. Hyperhomocystein should be considered as a risk factor for cardiovascular diseases in humans $[4,18]$.

According to the studies in the field of veterinary medicine about acute selenium deficiency in lambs, it was indicated that homocysteine levels in the lambs with acute cardiac form was higher than the lambs with muscular dystrophy form [1]. Kozat et al. (2011) reported that homocysteine levels of lambs with subclinical white muscle disease were significantly higher than the homocysteine levels of healthy lambs $(\mathrm{P}<0.001)[19]$.

In their research on the homocysteine levels in cats with cardiomyopathy and thromboembolism, McMichael et al. (2011) [11] were able to identify that homocysteine levels in cats are respectively; $6.7 \pm 4.1 \mathrm{mmol} / \mathrm{L}$ for healthy cats, $10.1 \pm 6.10 \mathrm{mmol} / \mathrm{L}$ for cats with cardiomyopathy and $8.0 \pm 4.1 \mathrm{mmol} / \mathrm{L}$ for cats with thromboembolism. According to the obtained data, homocystein level of healthy cats is statistically higher than cats with cardiomyopathy $(\mathrm{P}<0.05)$.

According to the literature searches about homocystein levels, there wasn't any data about plasma or serum homocysteine levels of cattle. In this study, the level of serum homocysteine of cows are respectively: $17.44 \pm 1.22 \mathrm{mmol} / \mathrm{L}$ for Simmental breed, $17.04 \pm$ $1.13 \mathrm{mmol} / \mathrm{L}$ for Holstein breed, and $16.35 \pm 1.24 \mathrm{mmol} / \mathrm{L}$ for Montafon. In the statistical evaluation of serum homocysteine levels of cattle, statistically no difference was detected between the three cultures breed $(\mathrm{P}>0.05)$ (Table 4). 
Levels of serum CK-MB, LDH, and AST which are often utilized especially in the diagnosis of heart diseases in human and veterinary medicine are only used to diagnose acute coronary events [20]. In this study, level of serum CK for Simmental cattle was $243.30 \pm 17.59 \mathrm{IU} / \mathrm{L}$, for Holstein cattle was $237.80 \pm 18.19 \mathrm{IU} / \mathrm{L}$ and Montafon breed was $273.25 \pm 02.29 \mathrm{IU} / \mathrm{L}$. Levels of serum CKMB were 287.42 $\pm 27.04 \mathrm{IU} / \mathrm{L}$ for Simmental breed, $311.33 \pm 31.81 \mathrm{IU} / \mathrm{L}$ for Holstein breed and $301.10 \pm 27.00 \mathrm{IU} / \mathrm{L}$ for Montafon breed (Table 2). In the assessments performed about breeds, statistically a significant variety wasn't detected about levels of serum $\mathrm{CK}$ and $\mathrm{CK}-\mathrm{MB}$ on the three breeds $(\mathrm{P}>0.05)$. There is a fact that these values were slightly higher than the values of researchers and it may be interpreted as a result of analysis method of CK enzyme.

Serum transaminase enzyme activities in animals vary according to age, sex, hunger, nutrition, stress and environmental factors [21]. Batmaz (1990) reported that there were no racial differences in enzyme activities of serum AST, ALT and LDH on 24-48 months Holstein and Montafon breed cattle [22]. In another study, it is reported that serum AST, ALT and LDH activities of 12-18 month old Holstein breed are respectively, $68.8 \pm 4.3,27.9 \pm 1.6$ and $1010 \pm 60 \mathrm{U} / \mathrm{L}$ [23].

In this study, activities of serum AST, ALT and LDH of cattle were respectively found for Simmental breed $93.40 \pm 5.11 \mathrm{IU} / \mathrm{L}, 31.33$ $\pm 1.96 \mathrm{IU} / \mathrm{L}$ and $1553.38 \pm 169.53 \mathrm{IU} / \mathrm{L}$, for Holstein breed $90.31 \pm 4.51,32.06 \pm 2.08$ and $1453.48 \pm 159.53 \mathrm{IU} / \mathrm{L}$, for Montafon breed $92.87 \pm 4.58,34.19 \pm 2.12$ and $1644.43 \pm 167.28 \mathrm{IU} / \mathrm{L}$. According to the assessments performed for breeds, serum AST, ALT, and LDH activities of the three breeds were statistically same ( $>0.05)$ (Table 2). Values of serum activities of AST, ALT, and LDH of three breeds were found close to each other. It is similar to the values reported by researchers $[21,23]$.

To learn about diseases of the circulatory system, as well as clinical examination, blood examinations are very important [24]. In the absence of cobalt in the rations, vitamin $B_{12}$ cannot be synthesized and this situation causes the deficiency of this vitamin in ruminants [25]. If the deficiency progresses, it causes such changes in the chart of red blood cells as hypoplastic, normocytic, normochromic anemia [24]. In the light of this idea, many scientific studies were done related to vitamin $\mathrm{B}_{12}$, and we think that it will be useful to evaluate the studies with hematological parameters.

On hematologic parameters in adult cattle, many researchers indicate [16,26-28]. Leukocytes as $4000-12000 / \mu \mathrm{L}$, platelets as 175 $620 \times 10^{3} / \mu \mathrm{L}$, hemoglobin as $8-15 \mathrm{~g} / \mathrm{dL}$, hematocrit as $26-42 \%$, and MCHC as $26-36 \mathrm{~g} / \mathrm{dL}$.

In this study, the values of hematologic parameters in healthy culture breed cows were mainly found close to each other. The comparative statistical analysis performed between breeds was not significant $(\mathrm{P}>0.05)$. It was determined that $\mathrm{WBC}$, hemoglobin, hematocrit, MCHC, and PLT values of breeds were similar to the data reported by the researchers [16,26-28].

Vitamin $B_{12}$ participates in various metabolic reactions in organism and it is primarily necessary for the phase of formaldehyde oxidation of monocarbon compounds and it is effective in the metabolism of nuclein. In humans, it is reported that deficiency of cobalamin in patients is associated with disorder of homocysteine and also these people have hyperhomocysteinemia [29,30]. It is reported that, the homocysteine levels of cats with aortic thromboembolism were higher than the healthy cats [12]. In their studies on vitamin $B_{12}$ levels in healthy adult cattle, İssi et al. (2010) found values as $155.13 \pm 19.74 \mathrm{pg} / \mathrm{ml}$ [17]. It is reported that McMichael et al. (2011) [11] have found the level of vitamin $B_{12}$ in healthy cats as $1650 \pm 700 \mathrm{pg} / \mathrm{mL}$ and in cats with cardiomyopathy as $939 \pm$ $389 \mathrm{pg} / \mathrm{mL}$ and in cats with thromboembolism as $866 \pm 367 \mathrm{pg} / \mathrm{mL}$ and they also stated that levels of vitamin $B_{12}$ in healthy cats are statistically and significantly higher than values of cats with cardiomyopathy and thromboembolism $(\mathrm{P}<0.001)$.

In this study, serum vitamin $B_{12}$ levels of Simmental, Holstein and Montafon breeds were found as $192.36 \pm 22.02,253.50 \pm 26.73$ and $183.74 \pm 22.22 \mathrm{pg} / \mathrm{mL}$, respectively. This is similar to the data of researchers [17,31]. In the statistical evaluation of serum homocysteine levels for three culture breed, there wasn't any difference $(\mathrm{P}>0.05)$ (Table 4).

Ruminants need cobalt for the synthesis of vitamin $B_{12}$ and vitamin $B_{12}$ is synthesized with adequate amount of cobalt. It is reported that remethylation of homocysteine was failed due to the deficiency of vitamin $B_{12}$, and this situation caused hyperhomocystein [13].

In this study, cobalt levels of Simmental, Holstein and Montafon breeds were obtained as $431.35 \pm 22.65,483.59 \pm 31.19$ and 458.26 $\pm 43.38 \mathrm{ppb}$, respectively. In the statistical evaluation of serum cobalt levels for three culture breed, difference wasn't detected $(\mathrm{P}>$ 0.05) (Table 4).

As a result, in this study clinical signs and hematological and biochemical parameters of age and breed of healthy culture breed cattle were found in accordance with the reference values stated for healthy cattle. It was concluded that serum homocysteine values obtained on the basis of breed and age of healthy cows should fulfill the necessity for diagnosis of heart and vascular diseases and in such kind of studies, it also may be a reference value for serum homocysteine levels of cows.

\section{Acknowledgement}

This study was supported by Head of Scientific Research Projects of Yüzüncü Yıl University as a project No. 2010-SBE-YL175.

\section{References}

1. Rezaei SA, Dalir-Naghadeh B (2009) Association of plasma and heart homocysteine and blood malondialdehyde with cardiovascular diseases induced by acute selenium deficiency in lambs. Small Rum Res 83: 22-8. 
2. Gauthier GM, Keevil JG, Mcbride PE (2003) The Association of homocysteine and coronary artery disease. Clin Cardiol 26: 563-8.

3. Lin G, Dongyan W, Yang L, Dingfang B, Lin C, et al. (2003) Homocysteine increases the synthesis of adrenomedullin in vascular fibroblasts of rats. Chinese Sci Bull 48: 983-7.

4. Hajjar KA (2001) Homocysteine: a sulph'rous fire. J Clin Invest 107: 663-4.

5. Chai AU, Abrams J (2001) Homocysteine: A New cardiac risk factor? Clin Cardiol 24: 80-4.

6. Derici ÜB, Reis KA (2002) Hiperhomosisteinemi ve kronik böbrek yetmezliği. Türk Nefroloji ve Diyaliz Transplantasyon Derg 1: 129 -34.

7. Levine J, Gur E, Loewenthal R, Vishne T, Dwolatzky T, et al. (2007) Plasma homocysteine levels in female patients with eating disorders. Int J Eat Disord 40: 277-84.

8. Reutens S, Sachdev P (2007) Homocysteine in neuropsychiatric disorders of the elderly. Int J Geriatr Psych 17: 859-64.

9. Bostom AG, Lathrop L (1997) Hyperhomocysteinemia in end stage renal disease: Prevalence, etiology, and potential relationship to atherosclerotic outcomes. Kidney Int 52: 10-20.

10. Üren N, Fidancı UR, Kırmızıgül AH, Findancı V, Pekcan M (2009) Kronik böbrek yetmezlikli kedilerde homosistein düzeyleri. Kafkas Univ Vet Fak Derg 15: 543-6.

11. McMichael M, Freeman LM, Selhub J, Rozanski EA, Brown DJ, et al. (2011) Plasma homocysteine, B vitamins, and amino acid concentrations in cats with cardiomyopathy and arterial thromboembolism. J Vet Intern Med 14: 507-12.

12. Ruaux CG, Steiner JM, Williams DA (2005) Early biochemical and clinical responses to cobalamin supplementation in cats with signs of gastrointestinal disease and severe hypocobalaminemia. J Vet Intern Med 19: 155-60.

13. Stangl GI, Schwarz FJ, Kirchgessner M (1998) Amino acid changes in plasma and liver of cobalt-deficient cattle. J Ani Physiol Ani Nutri 80: $40-8$.

14. O’Grady H, Kelly C, Bouchier-Hayes D, Leahy A (2002) Homocysteine and occlusive arterial disease. Brit J Surg 89: 838-44.

15. Castro R, Rivera I, Blom HJ, Jakobs C (2006) Homocysteine metabolism, hyperhomocysteinaemia and vascular disease, An overview. J Inherit Metab Dis 29: $3-20$.

16. Batmaz H (2010) Internal Diseases of Cattle In: Diagnosis from Symptom Diagnosis Diagnosis (2 ${ }^{\text {nd }}$ Edn) Bursa: F. Özsan Mat. Singing [Siğır İç hastalıkları semptomdan tanıya tanıdan sağaltıma, 2. Baskı, Bursa, Turkey: F. Özsan Mat San ve Tic Ltd Şti], Turkey.

17. İssi M, Gül Y, Başbuğ O, Şahin N (2010) Tropikal theileriozisli sığırlarda klinik, hematolojik ve bazı biyokimyasal parametreler ile serum kobalt ve B12 vitamin düzeyleri. Kafkas Univ Vet Fak Derg 16: 909-13.

18. Gorinstein S, Jastrzebski Z, Namiesnik J, Leontowicz H, Leontowicz M, et al. (2001) The atherosclerotic heart disease and protecting properties of garlic, contemporary data. Mol Nutr Food Res 51: 1365-81.

19. Kozat S, Altuğ N, Yüksek N, Özkan C (2011) Evaluation of the levels of homocysteine, troponin I, and nitric oxide in lambs with subclinical white muscle disease. Kafkas Univ Vet Fak Derg 17: 441-4.

20. Sugen B, Güneş V (2008) Beyaz kas hastalıklı kuzularda kalp kası hasarının teşhisinde kardiyak troponin kit analizleri ve serum enzim aktivitelerinin önemi. Erciyes Univ Sağ Bil Derg 17: 144-9.

21. Bulum KL, Mengi A (2000) Normal ve fascioliasisli sı̆̆ırlarda serum AST, ALT, GGT, ALP aktiviteleri ile total protein, albumin, total bilirubin düzeyleri üzerine araştırmalar. İstanbul Üniv Vet Fak Derg 26: 311-24.

22. Batmaz H (1990) Klinik olarak normal sığırlar ile traumatikli sığır teşhis ve prognozunda serum protein elektroforezi ve SGOT-SGPT ile LDH enzim düzeyleri üzerine karşılaştırmalı araştırmalar. Doğa Tr Vet Anim Sci 14: 467-78.

23. Bilal T, Uysal A, Bilal T, Tan H (1995) Şeker pancarı posası ile beslenen ve beslenmeyen besi danaların bazı kan parametreleri üzerine araştırmalar. İstanbul Üniv Vet Fak Derg 21: 272-8.

24. İmren HY (2003) Veteriner İç Hastalıklarına Giriş, 4.Baskı. Ankara, Turkey: Medisan Yayınevi

25. Stangl GI, Schwarz FJ, Jahn B, Kirchgessner M (2000) Cobalt-deficiency-induced hyperhomocysteinaemia and oxidative status of cattle. British J Nutri 83: 3-6.

26. Aiello SE (1998) Traumatic reticuloperitonitis, hemostatic disorders, haematologic reference ranges, In: Aiello SE editör. The Veterinary Merck Manual ( $8^{\text {th }}$ Edn) Pennsylvania, Merck \& Co. İnc., USA.

27. Bozukluhan K, Gökce İH (2007) Reticuloperitonitis traumatica (RPT) and of traumatic Pericarditis (PT) 's clinical in cattle, the investigation of hematological and biochemical parameters [Retikuloperitonitis travmatika (RPT) ve perikarditis travmatika (PT)'lı sığırlarda klinik, hematolojik ve biyokimyasal parametrelerin araştırılması]. Erciyes Üniv Vet Fak Derg 4: 97-107.

28. Gökçe G, Paşa S, Öcal N (1998) Theileriosisli sığırlarda bazı kan parametreleri, kan gazları ve idrar analizleri. Kafkas Univ Vet Fak Derg 4: 43-7.

29. Allen RH, Stabler SP, Savage DG, Lindenbaum J (1993) Metabolic abnormalities in cobalamin (vitamin B12) and folate deficiency. Faseb J 7: $1344-53$.

30. Ruaux CG, Steiner JM, Williams DA (2001) Metabolism of amino acids in cats with severe cobalamin deficiency. Am J Vet Res 62: $1852-8$.

31. Korpela H, Mykkänen HM (1983) Serum Vitamin B12 levels in clinically normal and ketotic dairy cows. Zentralblatt für. Veterinärmedizin Reihe A 30: 337-40. 


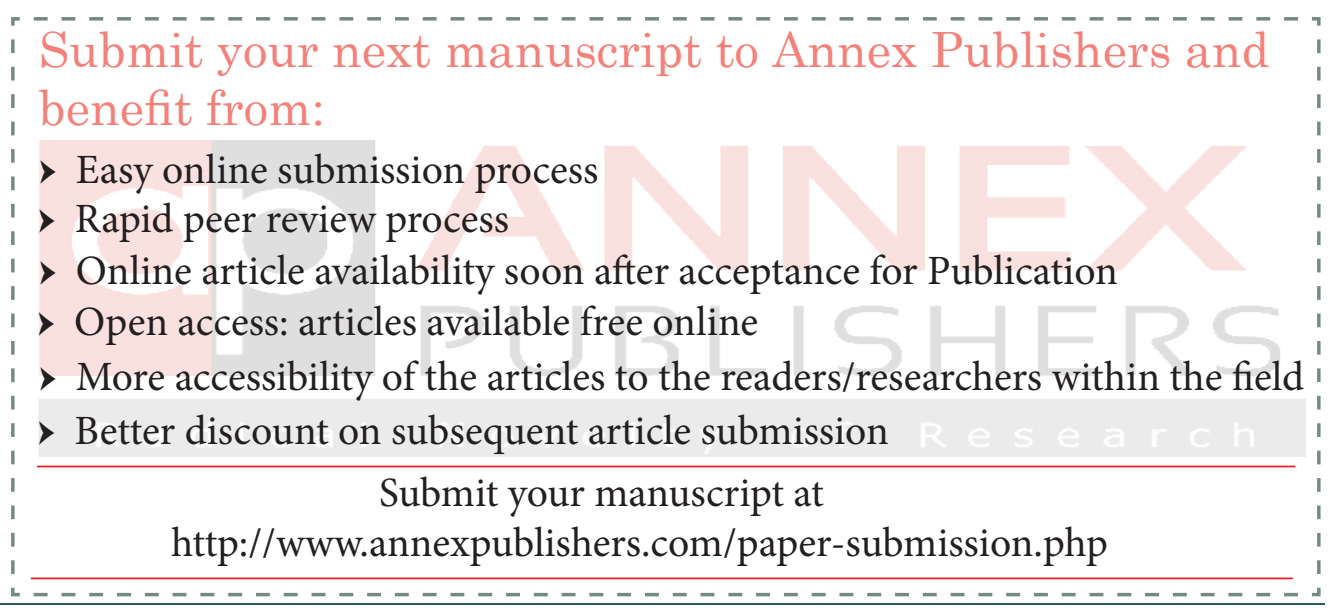

